\title{
NATURAL REGENERATION IN ABANDONED FIELDS FOLLOWING INTENSIVE AGRICULTURAL LAND USE IN AN ATLANTIC FOREST ISLAND, BRAZIL
}

Milene Silvestrini ${ }^{2}$, Airton de Deus Cysneiro ${ }^{3}$, Aline Lopes Lima ${ }^{3}$, Larissa Giorgeti Veiga ${ }^{3}$, Ingo Isernhagen $^{4}$, Jorge Yoshio Tamashiro ${ }^{5}$, Sergius Gandolfi ${ }^{6}$ e Ricardo Ribeiro Rodrigues ${ }^{6}$

\begin{abstract}
The time required to regrowth a forest in degraded areas depends on how the forest is removed and on the type of land use following removal. Natural regeneration was studied in abandoned old fields after intensive agricultural land use in areas originally covered by Brazilian Atlantic Forests of the Anchieta Island, Brazil in order to understand how plant communities reassemble following human disturbances as well as to determine suitable strategies of forest restoration. The fields were classified into three vegetation types according to the dominant plant species in: 1) Miconia albicans (Sw.) Triana (Melastomataceae) fields, 2) Dicranopteris flexuosa (Schrader) Underw. (Gleicheniaceae) thickets, and 3) Gleichenella pectinata (Willd.) Ching. (Gleicheniaceae) thickets. Both composition and structure of natural regeneration were compared among the three dominant vegetation types by establishing randomly three plots of $1 \times 3 \mathrm{~m}$ in five sites of the island. A gradient in composition and abundance of species in natural regeneration could be observed along vegetation types from Dicranopteris fern thickets to Miconia fields. The gradient did not accurately follow the pattern of spatial distribution of the three dominant vegetation types in the island regarding their proximity of the remnant forests. A complex association of biotic and abiotic factors seems to be affecting the seedling recruitment and establishment in the study plots. The lowest plant regeneration found in Dicranopteris and Gleichenella thickets suggests that the ferns inhibit the recruitment of woody and herbaceous species. Otherwise, we could not distinguish different patterns of tree regeneration among the three vegetation types. Our results showed that forest recovery following severe anthropogenic disturbances is not direct, predictable or even achievable on its own. Appropriated actions and methods such as fern removal, planting ground covers, and enrichment planting with tree species were suggested in order to restore the natural forest regeneration process in the abandoned old fields.
\end{abstract}

Keywords: Wet tropical forests, Anthropogenic disturbances and Forest restoration.

\section{REGENERAÇÃO NATURAL EM ÁREAS ABANDONADAS APÓS INTENSIVO USO DO SOLO EM UMA ILHA ORIGINALMENTE COBERTA PELA FLORESTA TROPICAL ATLÂNTICA, BRASIL}

\begin{abstract}
RESUMO - O tempo necessário para a regeneração de uma floresta em áreas degradadas depende de como a floresta foi removida e do tipo de uso do solo após o desmatamento. A regeneração natural foi estudada em campos abandonados após intensivo uso agrícola em áreas originalmente cobertas por Floresta Atlântica na Ilha Anchieta, Ubatuba, Brasil, com o objetivo de entender como as comunidades vegetais se re-estruturam após perturbações antrópicas e determinar estratégias apropriadas de restauração florestal. Os campos foram classificados em três tipos de vegetação, em função da espécie vegetal dominante: 1) campos de Miconia
\end{abstract}

\footnotetext{
${ }^{1}$ Recebido em 10.11.2011 e aceito para publicação em 28.05.2012.

${ }^{2}$ Programa de Pós-Graduação em Ecologia pela Universidade Estadual de Campinas (UNICAMP). E-mail: <milene.silvestrini@gmail.com>, ${ }^{3}$ Programa de Pós-Graduação em Biologia Vegetal pela Universidade Estadual de Campinas (UNICAMP). E-mail:<airtoncys@ gmail.com>, $<$ allbio03@gmail.com>e <lagiveiga@gmail.com>.

${ }^{4}$ Empresa Brasileira de Pesquisa Agropecuária (EMBRAPA) Agrossilvipastoril. E-mail: <ingo.isernhagen@embrapa.br>.

${ }^{5}$ Universidade Estadual de Campinas (UNICAMP), Instituto de Biologia, Departamento de Biologia Vegetal. E-mail: <tamashi@unicamp.br>.

${ }^{6}$ Universidade de São Paulo, Escola Superior de Agricultura Luiz de Queiroz, Departamento de Botânica. E-mail: <sgandolf@ usp.br> e $<$ rrr@usp.br>.
} 
albicans (Sw.) Triana (Melastomataceae), 2) gleicheniais de Dicranopteris flexuosa (Schrader) Underw. (Gleicheniaceae) e 3) gleicheniais de Gleichenella pectinata (Willd.) Ching. (Gleicheniaceae). A composição e estrutura da regeneração natural foram comparadas entre os três tipos de vegetação, delimitando-se aleatoriamente três parcelas de $1 \mathrm{~m} \times 3 \mathrm{~m}$, em cinco locais da ilha. Foi observado um gradiente na composição e abundância de espécies na regeneração natural ao longo dos três tipos de vegetação, dos gleicheniais de Dicranopteris até os campos de Miconia. Esse gradiente não seguiu exatamente o mesmo padrão de distribuição dos três tipos de vegetação na ilha em relação à proximidade com os remanescentes florestais. Uma complexa associação de fatores bióticos e abióticos parece estar afetando o recrutamento e estabelecimento das plântulas nas parcelas estudadas. A baixa regeneração de plantas nos gleicheniais de Dicranopteris e Gleichenella sugere o efeito inibitório das samambaias sobre o recrutamento de espécies herbáceas e arbustivo-arbóreas. Entretanto, não foi possível distinguir diferentes padrões de regeneração arbórea entre os três tipos de vegetação. Os resultados indicaram que a regeneração florestal após distúrbios antrópicos intensos não é direta, previsível ou, mesmo, alcançável por si só. Ações e técnicas apropriadas para cada área, como remoção das samambaias, cobertura de solo e enriquecimento com espécies arbóreas foram sugeridas, visando à restauração da regeneração natural dos campos e ao seu retorno às condições florestais.

Palavras-chave: Florestas tropicais úmidas, Distúrbios antrópicos e Restauração florestal.

\section{INTRODUCTION}

Patterns of forest regeneration following anthropogenic disturbances are influenced by the type and the intensity of the disturbance (KENNARD et al., 2002; RODRIGUES; GANDOLFI, 2000; UHL et al., 1982). This is directly related to the effects of human activity on the ecological processes driving forest dynamics, such as seed dispersal, sprouting, seedling recruitment, seedling establishment, and plant growth. Understanding these processes and how they are affected by land use is critical to define strategies for forest restoration in abandoned agricultural areas as well as for forest management, conservation and monitoring (TABANEZ et al., 1997; TORRES et al., 1997; TABARELLI; MANTOVANI, 1999).

The process of deforestation and fragmentation in Atlantic Forest has been well reported since the beginning of European colonization in Brazil in the $16^{\text {th }}$ century (DEAN, 1995). Coastal areas and islands have been further threatened mainly by tourism exploitation and real state enterprises (PANIZZA, 2004). Abandoned areas following logging, clear cut, grazing, and agricultural activities are very frequent all over the Brazilian coast (LEITÃO-FILHO, 1987; PANIZZA, 2004). Some of them exhibit a total or partial recovery while others have become abandoned fields without generating a forest structure (TABARELLI et al., 2010). The Anchieta Island State Park (AISP), located at Anchieta Island in the northern coast of São Paulo State, has been extensively disturbed by human occupation. The original Atlantic forests were stripped mainly by logging, agriculture, cattle and goat grazing (Guillaumon et al., 1989). The over exploitation and harm was more severe after the installation of a prison on the island in 1928, followed by the introduction of fifteen alien species of mammals and two alien species of reptiles in 1983 (BOVENDORP; GALETTI, 2007; GUILLAUMON et al., 1989).

Despite the degradation, remnant forest fragments near the most disturbed areas of the island could be a source of plant propagules for autogenic restoration. However, we verified that the abandoned areas have not showed the expected secondary succession even with this proximity and after the end of agricultural and goat grazing activities since the creation of the Park in 1977 (MUÑIZ-CASTRO, et al. 2006; UHL et al.,1982). This fact suggests that some or several ecological processes that might regulate forest regeneration dynamics have been affected by the intensive human activities in the disturbed areas and require further investigation to determine suitable strategies of ecological restoration. Nowadays, most of the abandoned areas are heavily colonized by Miconia albicans (Sw.) Triana (Melastomataceae) in the core regeneration, forming the so called Miconia field; following the radius from this central Miconia field, we find fern thicket areas dominated by Dicranopteris flexuosa (Schrader) Underw. (Gleicheniaceae); finally, the outer area is also a fern thicket, but dominated by Gleichenella pectinata (Willd.) Ching. (Gleicheniaceae) until the forest edge (GUILLAUMON et al., 1989). This pattern of spatial distribution of dominant species all over the severely disturbed sites

Revista Árvore, Viçosa-MG, v.36, n.4, p.659-671, 2012 
of the island, and the fact of the species exhibiting different degrees of soil cover, shading and possible allelopathic effects (MÜLLER et al., 2007; SOARES; VIEIRA, 2000), may be related to the natural regeneration process and the consequent absence of a forest recovery in the abandoned old fields. The knowledge of composition and structure of the natural regeneration under these new plant communities may help to understand the role of the different vegetation types on the seedling recruitment and establishment processes following severe anthropogenic disturbances, as well as to determine the most suitable forest restoration techniques for areas with similar land uses.

The objective of this study was to characterize the composition and structure of the natural regeneration in the abandoned old fields following intensive agricultural land use of Anchieta Island, by comparing the effects of the three different vegetation types on the seedling recruitment and establishment.

\section{MATERIALS AND METHODS}

\subsection{Study site}

Anchieta Island $\left(23^{\circ} 27^{\prime}-23^{\circ} 34^{\prime} \mathrm{S} ; 45^{\circ} 02^{\prime}-45^{\circ} 04^{\prime}\right.$ W) is located in Ubatuba, north coast of São Paulo State, Brazil (Figure 1). The island is the second largest on the northern coast of the state, with 828 ha and $17 \mathrm{~km}$ of perimeter (SMA, 1998). The local climate corresponds to Köppen's "Cfb", that is, tropical rainy without dry season (SETZER, 1966). Mean rainfall and temperature are $2104 \mathrm{~mm} \mathrm{yr}^{-1}$ and $24^{\circ} \mathrm{C}$, respectively. Altitude ranges from 0 to $339 \mathrm{~m}$ asl. The steeps are formed by Cambisols (Inceptisols) and the valleys by Gleysols (Entisols) (GUILLAUMON et al., 1989).

The predominant vegetation of the island is the lowland and premontane Atlantic Forest, classified as ombrofilous dense forest (IBGE, 1992) and wet subtropical forest (SENSU HOLDRIDGE, 1967). Currently, Anchieta Island is covered by forests in different levels of anthropogenic disturbances and successional stages; restingas; saxicolous vegetation; mangrooves; beaches and rocky shores (GUILLAUMON et al., 1989).

The study was carried out in both fern thickets and Miconia fields, which are areas with different patterns of vegetation composition and structure, resulted from the natural regeneration process during 31 years of abandonment after intensive land use (GUILLAUMON et al., 1989). The study area was classified into three different vegetation types according to the dominant plant species: Miconia albicans (Melastomataceae) fields (M), Dicranopteris flexuosa (Gleicheniaceae) thickets (D), and Gleichenella pectinata (Gleicheniaceae) thickets (G) (GUILLAUMON et al., 1989).

Five sites in the island that presented these three vegetation types described above were selected for the study:

Site 1 (S1) - near Praia Grande: height above sea level of $15-50 \mathrm{~m}$, slopes between $18^{\circ}$ and $36^{\circ}$, with a mean slope angle of $24^{\circ}$.

Site 2 (S2) - near Praia do Engenho: height above sea level of 0-35 m, slopes between $10^{\circ}$ and $32^{\circ}$, with a mean slope angle of $19^{\circ}$.

Site 3 (S3) - near Reservoir trail: height above sea level of 75-95 m, slopes between $21^{\circ}$ and $46^{\circ}$, with a mean slope angle of $33^{\circ}$.

Site 4 (S4) - near Praia do Sul trail: height above sea level of $50-65 \mathrm{~m}$, slopes between $16^{\circ}$ and $23^{\circ}$, with a mean slope angle of $18^{\circ}$.

Site 5 (S5) - near Praia do Leste trail: height above sea level of 90-120 m, slopes between $19^{\circ}$ and $36^{\circ}$, with a mean slope angle of $26^{\circ}$.

In general, sites presented similar levels of anthropogenic disturbance, i.e., an intensive and prolonged land use. Basically, local forests were cleared, and following land use comprised several years of farming (agriculture and domestic animals) during the prison period (19041954), goat-grazing after prison closing, and abandoning when AISP was created in 1977 (REIS-DUARTE, 2004; GUILLAUMON et al., 1989; V. BUCHIANERI, personal communication). However, differences regarding the crop culture and civil constructions among sites were noted. Banana, rice, beans, castor, coffee, and manhiot were cultivated at $\mathrm{S} 1$; sugarcane at $\mathrm{S} 2$; manhiot, beans, and sugarcane at $\mathrm{S} 4$. A road and an old sugar mill were built in part of $\mathrm{S} 2$ when the prison was active; a village in part of S3; a fishing village at S4; and a small brick factory at S5 (V. BUCHIANERI, personal communication).

\subsection{Study design}

The five study sites were located relatively near to each other (Figure 1) and were equidistant from nearby remnant forests. In every site, we randomly located

Revista Árvore, Viçosa-MG, v.36, n.4, p.659-671, 2012

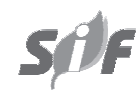


three $1 \mathrm{~m}$ x $3 \mathrm{~m}$ plots on each vegetation type. A total of $45 \mathrm{~m}^{2}$ for each vegetation type was sampled. In March 2008, all regenerating individuals in each plot were identified and quantified, and plant height was measured. We considered as regenerating individuals all individuals presented at plots, except the Dicranopteris flexuosa, Gleichenella pectinata and Miconia albicans individuals. All sampled species were classified according to the growth habit. In addition, all individuals were classified into the following six height classes: Class I - plants from 0 to $0.50 \mathrm{~m}$, Class II - plants $>0.50$ to
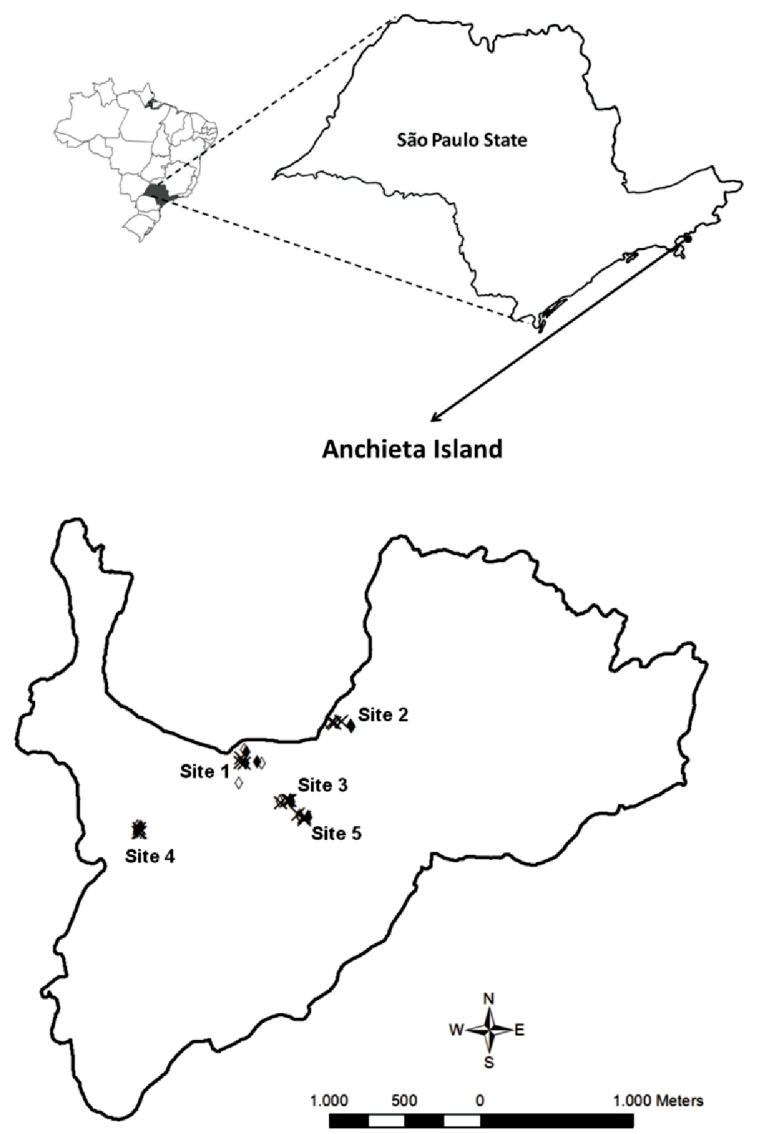

Figure 1 - Map of the Anchieta Island, Ubatuba, Brazil showing the location of the study plots in the five sites of the island. The different symbols show the plots of the Miconia (X), Dicranopteris $(\bullet)$, and Gleichenella $(\diamond)$ vegetation types.

Figura 1 - Mapa da Ilha Anchieta, Ubatuba, Brasil, mostrando a localização das parcelas estudadas nos cinco locais da ilha. Os diferentes símbolos indicam as parcelas dos tipos de vegetação Miconia $(X)$, Dicranopteris $(\diamond)$ e Gleichenella $(\diamond)$.
$1.00 \mathrm{~m}$, Class III - plants $>1.00$ to $1.50 \mathrm{~m}$, Class IV plants $>1.50$ to $2.00 \mathrm{~m}$, Class V - plants $>2.00$ to $2.50 \mathrm{~m}$, Class VI - plants $>2.50 \mathrm{~m}$. We also quantified the presence of dead plants.

\subsection{Sample collection and identification}

Plant material was identified by field observations, using specialized literature, comparing with material at UEC Herbarium (Universidade Estadual de Campinas) and with the support of experts whenever necessary. Plant material was deposited at UEC Herbarium. The scientific names were updated and standardized according to the Missouri Botanical Garden (http://www.tropicos.org/ Home.aspx). Some specimens were not identified to genus or species level due to the absence of fertile samples.

\subsection{Data analysis}

The vegetation types and sites were compared according to species composition, species richness and diversity (Shannon diversity index - H'), plant density (individuals $\mathrm{m}^{-2}$ ), tree richness, tree density (individuals $\mathrm{m}^{-2}$ ), mean height (mean value of each plot), maximum height (value of the highest individual of each plot), number of individuals per habit, number of species per habit, number of individuals per height class, number of dead plants (individuals $\mathrm{m}^{-2}$ ), and number of exclusive species (species that occurred exclusively in one of the three vegetation types). For most analyses, the three plots on same vegetation type at each site were merged in order to have a sufficient sample size.

\subsubsection{Univariate analyses}

Statistical differences were checked by comparing medians through the notched box plots (MCGILL et al., 1978) using Systat 11 software (Systat Software Inc., Richmond, CA). Hutcheson method was used to test differences in Shannon diversity index (H') (MAGURRAN, 1988). Differences in height class distributions and in habit distributions were tested using the Kolmogorov-Smirnov test. These distributions of plant species into habit and individuals into habit and height class were analyzed per vegetation types and per study sites in order to have a sufficient sample size (SOKAL; ROHLF, 1995).

\subsubsection{Multivariate analyses}

Both species composition and abundance in natural regeneration for the three vegetation types were compared 
by using correspondence analysis (CA) and cluster analysis after logarithmic normalization of the data $(\log +1)$. Cluster analysis was performed using the matrix distance based on Canberra metric (LANCE; WILLIAMS, 1966). Canberra metric was used to compute distances in order to increase contribution of rare species. Also, we excluded double-zeros to avoid indetermination (LEGENDRE; LEGENDRE, 1998). For the cluster analysis, single linkage agglomerative clustering, complete linkage agglomerative clustering, unweighted arithmetic average clustering (UPGMA), and Ward's minimum variance methods were evaluated. The cophenetic coefficient between the matrix of distances and the dendrogram was computed. The clustering method, with higher cophenetic correlation and that better represented the $\mathrm{CA}$ and univariate results, was presented (UPGMA). Multivariate analyses were performed using FITOPAC 2 software (SHEPHERD, 2009).

\section{RESULTS}

In the five sites surveyed, there were a total of 698 individuals belonging to 64 species and 28 families. Forty-seven percent of the species were herbs, 23\% shrubs, $24 \%$ trees and $6 \%$ lianas (Figure 2). From the total sampled individuals, $42.5 \%$ were shrubs, followed by $39.5 \%$ of herbs and $15.5 \%$ of trees.

The distribution of plant species into growth habit was statistically similar between sites and vegetation types (Figure 2a). Kolmogorov-Smirnov tests resulted in probabilities ranging from 0.07 to 0.87 when comparing distributions of plant species into growth habit between all pairs of sites and from 0.09 to 0.55 when comparing distributions among all pairs of vegetation types. Distribution of individuals into growth habit significantly differed between sites S3 and S1 ( $p=0.009), \mathrm{S} 3$ and S5 ( $p=0.0001), \mathrm{S} 4$ and S5 ( $p=0.0025)$ (Figure 2b). S2 showed a larger number of shrubs and herbs than all other sites. Only the Gleichenella vegetation type presented a significantly different individual distribution into growth habit. Gleichenella fern thickets presented roughly similar number of trees, but lower number of shrubs, herbs, and absence of lianas, which differed it from both Miconia fields ( $p<0.0001)$ and Dicranopteris fern thickets $(p=0.0049)$.

Species richness and diversity ( $\left.\mathrm{H}^{\prime}\right)(p<0.05$, probabilities not shown) were statistically higher in the Miconia fields than the fern thickets for most of

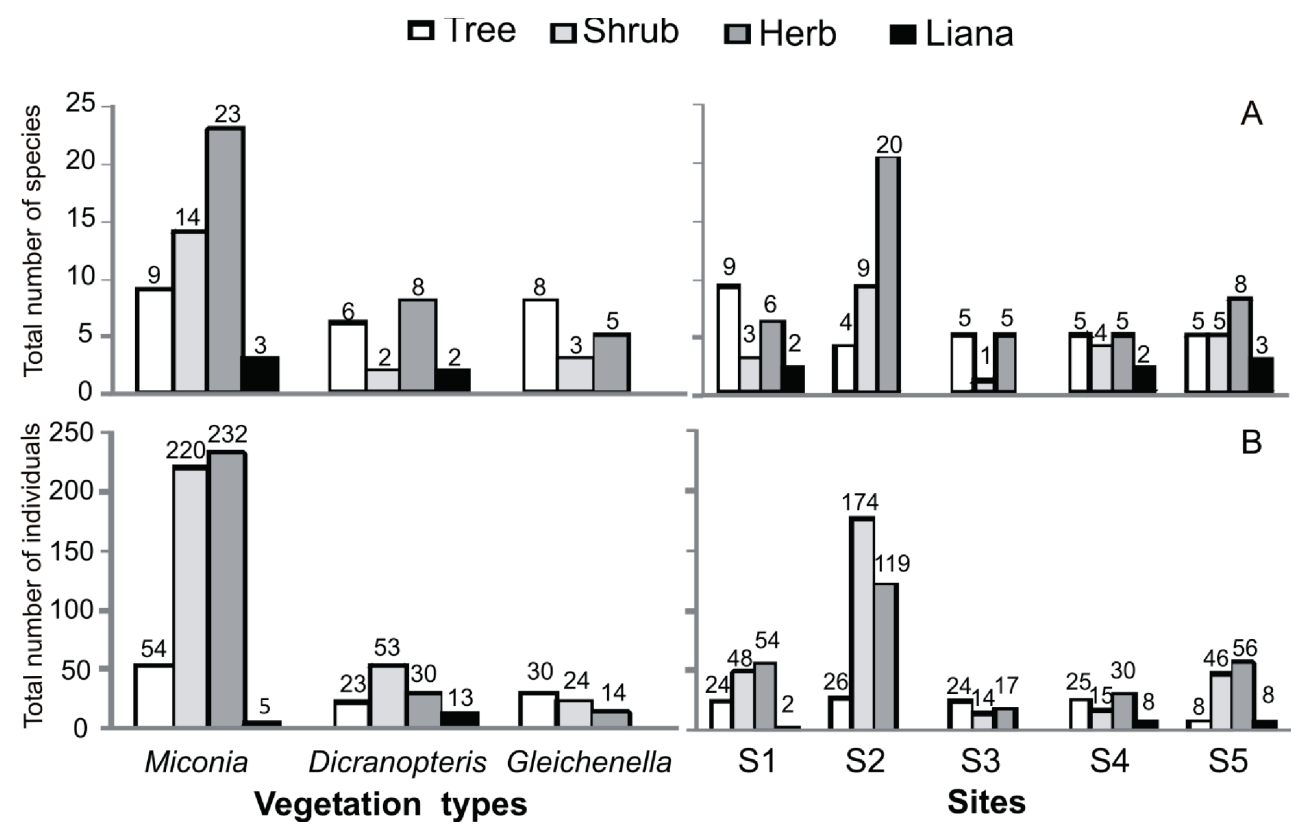

Figure 2 - Distribution of plant species (a) and individuals (b) into growth habit in natural regeneration in Anchieta Island, Ubatuba, Brazil (per vegetation type and study site).

Figura 2 - Distribuição de espécies (a) e indivíduos vegetais (b) em hábitos de crescimento amostrados na regeneração natural da Ilha Anchieta, Ubatuba, Brasil (por tipo de vegetação e local de estudo). 
the pairwise comparisons (Figure 3a). Values of H' were the following ( 3 plots merged): MS $1=1.666 ; \mathrm{MS} 2=$ $2.583 ; \mathrm{MS} 3=1.910 ; \mathrm{MS} 4=2.078 ; \mathrm{MS} 5=1.955 ; \mathrm{DS} 1$ $=1.409 ; \mathrm{DS} 2=1.450 ; \mathrm{DS} 3=0.0000 ; \mathrm{DS} 4=1.332 ; \mathrm{DS} 5$ $=1.074 ; \mathrm{GS} 1=1.956 ; \mathrm{GS} 2=1.040 ; \mathrm{GS} 3=1.530 ; \mathrm{GS} 4$ $=0.796 ;$ and GS5 $=0.956$. MS2 (Praia do Engenho) presented the highest species richness and diversity $(\mathrm{p}<0.0002)$, and density of individuals (Figures 3a and 3b). By analyzing the composition of species, we observed that 39 species (61\% of the total number of species) were exclusive of one out of the 15 plots (three merged). However, the species that occurred in only one plot were found mostly at the Miconia fields: 16 were at MS2 (41\%), $13(33 \%)$ were at the other four Miconia sites, and only 5 species (13\%) and 5 species (13\%) were found at the Dicranopteris and Gleichenella plots, respectively. By comparing only the trees, there was no different pattern of regeneration between the three vegetation types, but we observed differences in both species richness and tree density among some sites (Figures $3 \mathrm{c}$ and $3 \mathrm{~d}$ ).
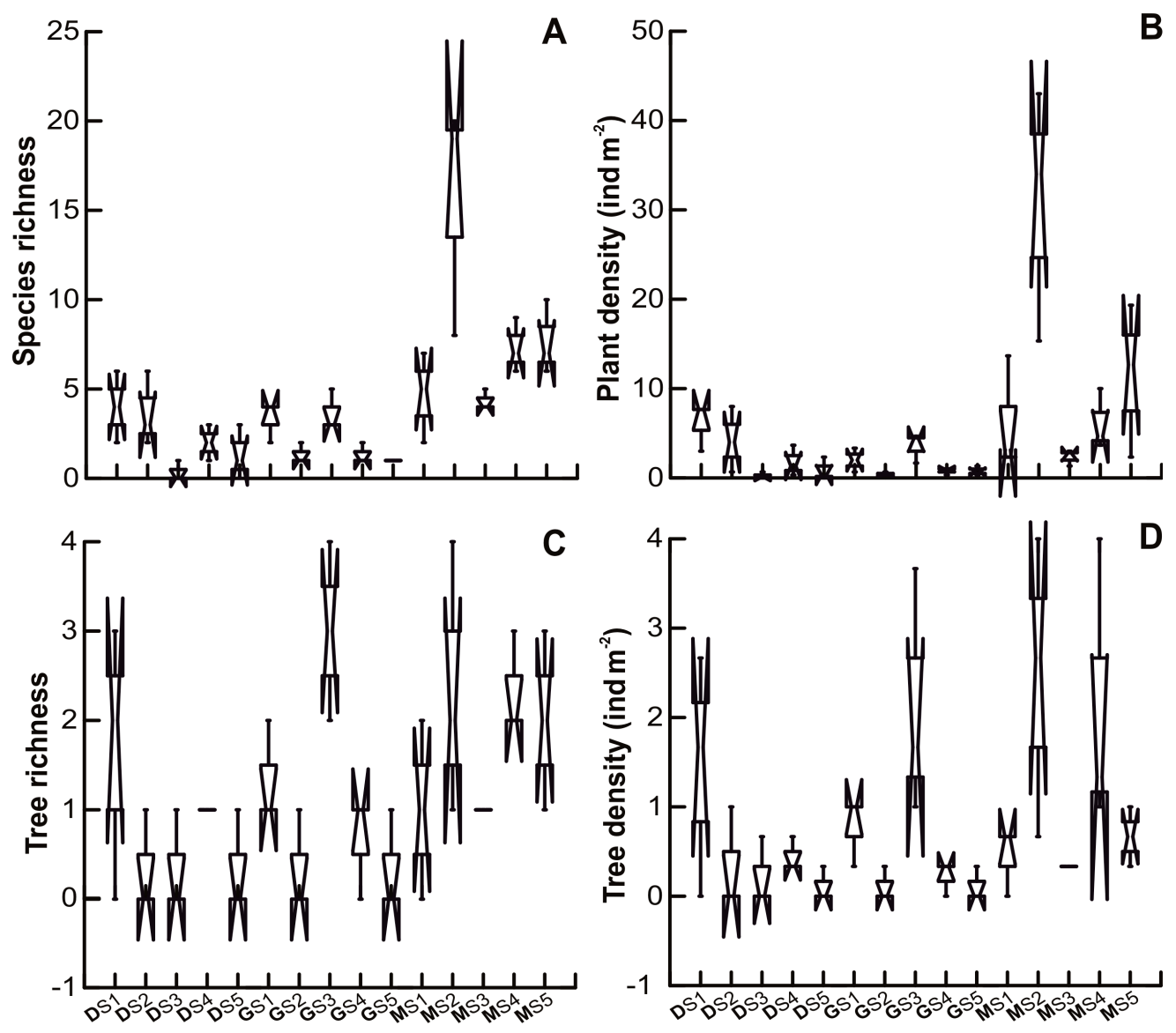

Vegetation types

Figure 3 - Notched box plots of species richness (a), plant density (ind $\mathrm{m}^{-2}$ ) (b), tree richness (c), and tree density (ind $\mathrm{m}^{-2}$ ) (d) sampled in natural regeneration under the Miconia (M), Dicranopteris (D), and Gleichenella (G) vegetation types at the five study sites (S1, S2, S3, S4, S5) in Anchieta Island, Ubatuba, Brazil. Overlapping of median confidence intervals indicates similarity of groups with $95 \%$ confidence level.

Figura 3 - Notched box plots da riqueza das espécies (a), densidade de plantas (ind $\left.m^{-2}\right)(b)$, riqueza de espécies arbóreas (c) e densidade de árvores $\left(\right.$ ind $\left.\mathrm{m}^{-2}\right)(\mathrm{d})$ amostradas na regeneração natural sob os tipos de vegetação Miconia $(M)$, Dicranopteris (D) e Gleichenella (G) nos cinco locais de estudo (S1, S2, S3, S4, S5) da Ilha Anchieta, Ubatuba, Brasil. Sobreposição de intervalos de confiança da mediana indicam semelhança entre grupos, com 95\% de confiança.

Revista Árvore, Viçosa-MG, v.36, n.4, p.659-671, 2012 
Plants sampled in the Miconia fields showed lower mean height values than in Gleichenella fern thickets, but they were in the same range of Dicranopteris fern thickets (Figure 4a). Maximum height was the highest in the site 3 of Gleichenella fern thickets (Figure 4b). Considering individual distributions in height classes, most of the sampled individuals were less than 0.50 $\mathrm{m}$ (class I), followed by individuals with 0.50 to 1.00 $\mathrm{m}$ (class II). Taller individuals were found in the Dicranopteris and Gleichenella fern thickets $(\mathrm{p}<0.05)$, except for DS4 and DS5 plots, while in the Miconia fields, we found $96 \%$ of individuals with height lower than $1 \mathrm{~m}$. Number of dead plants was greater in the sites 2 and 3 of Gleichenella fern thickets (Figure 4c).

Correspondence analysis indicated a gradient in composition and abundance of natural regeneration along vegetation types from Dicranopteris fern thickets to Miconia fields (Figure 5a). The eigenvalue of the first axis was 0.640 and that of the second axis was 0.537 . The explained percentage of inertia in the species data was $13.84 \%$ for the first axis and $11.62 \%$ for the second. The low percentage of inertia indicated that there were other factors affecting abundance and composition of species in our study plots. The hierarchical clustering analysis presented in figure $5 \mathrm{~b}$ confirmed the CA results. The extreme of gradient, the outlier MS2, was grouped apart from the others followed by the lower outliers GS4, DS5 and GS5. The analysis also indicated two major clusters comprising grouped plots of Miconia fields (except for MS3 and the above mentioned MS2) and fern thickets. However, groups of Gleichenella and Dicranopteris vegetation types could not be clearly distinguished. Also, although some plots were grouped together, the sites of Miconia fields were distantly related to each other. The cophenetic correlation $(r=0.80)$ indicated that the clustering of plots demonstrated in the dendrogram accurately represented the estimates of Canberra metric distances. All the hierarchical clustering methods tested showed evidences of the gradient in the natural regeneration (results not shown), but varied in the grouping of the outliers and extremes of gradient MS2, DS3, GS4, GS5, and DS5.

\section{DISCUSSION}

A gradient in composition and abundance of species in natural regeneration was observed along vegetation types from Dicranopteris fern thickets to Miconia fields in CA analysis (Figure 5a). The gradient did not
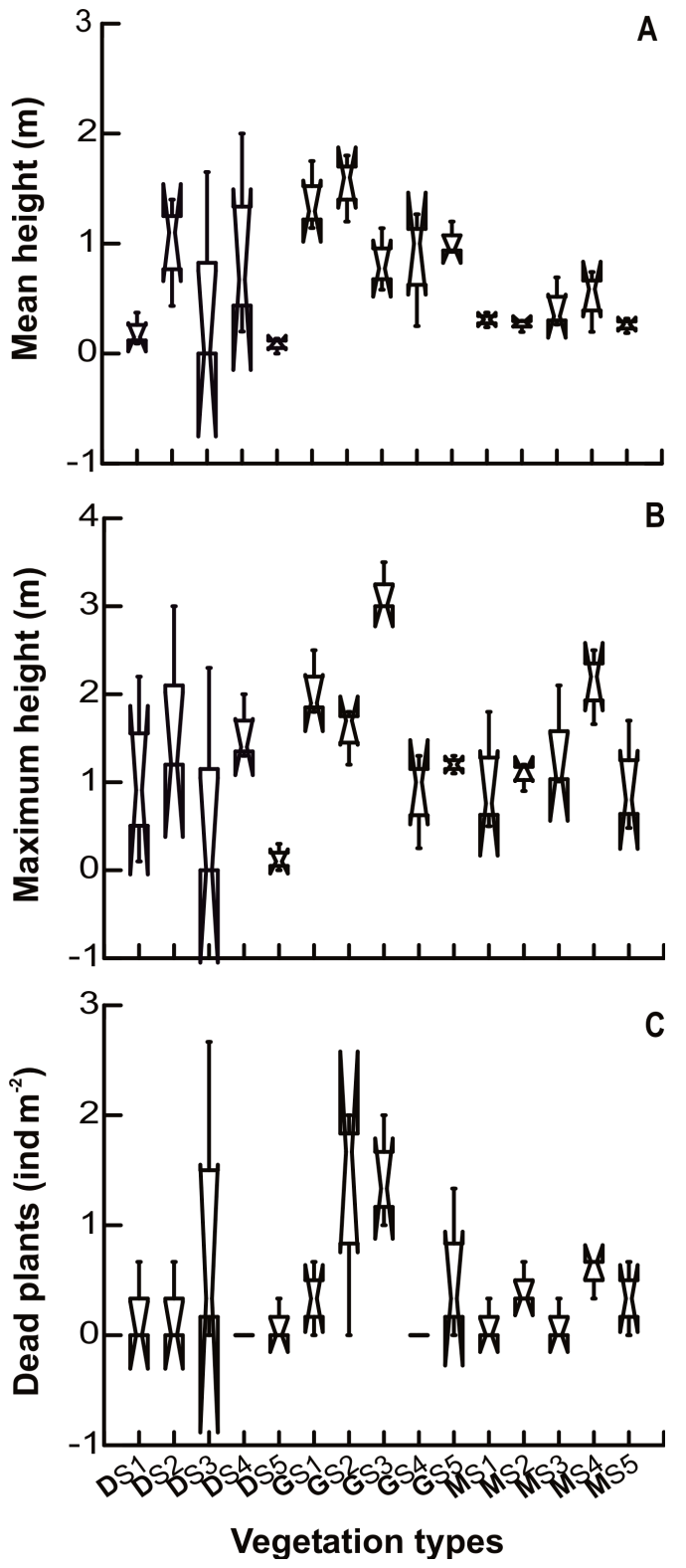

Figure 4-Notched box plots of mean height of the individuals (a) (m), maximum height of the individuals (b) $(\mathrm{m})$, and number of dead plants (ind $\mathrm{m}^{-2}$ ) (c) sampled in natural regeneration in Anchieta Island, Ubatuba, Brazil. See symbols, abbreviations, and details about notched box plots in figure 3 .

Figura 4-Notched box plots da altura média dos indivíduos (a) (m), altura máxima dos indivíduos $(b)(m)$ e número de plantas mortas (ind $\left.m^{-2}\right)(c)$ amostrados na regeneração natural da Ilha Anchieta, Ubatuba, Brasil. Vide símbolos, abreviações e detalhes dos notched box plots na figura 3.

Revista Árvore, Viçosa-MG, v.36, n.4, p.659-671, 2012 


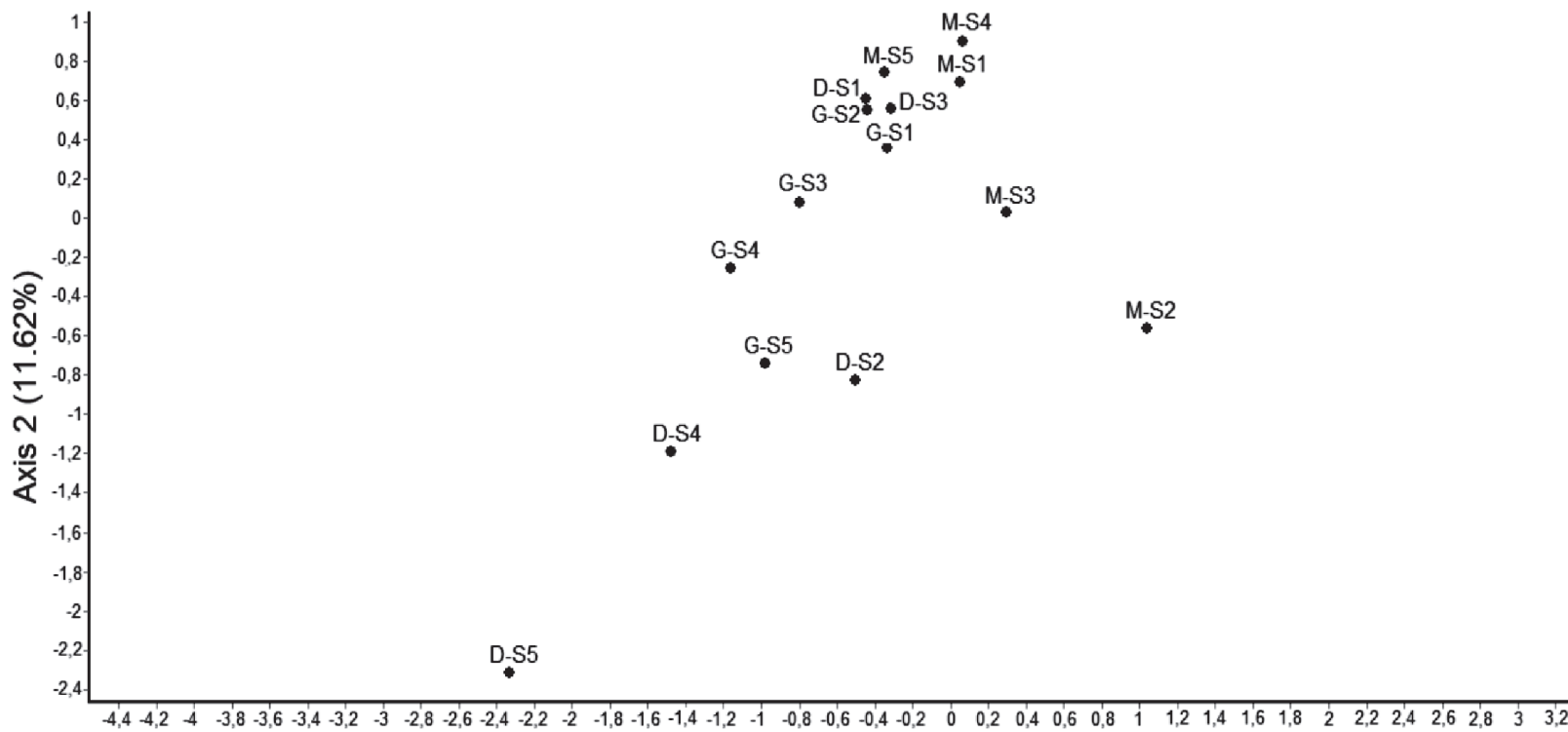

Axis $1(13.84 \%)$

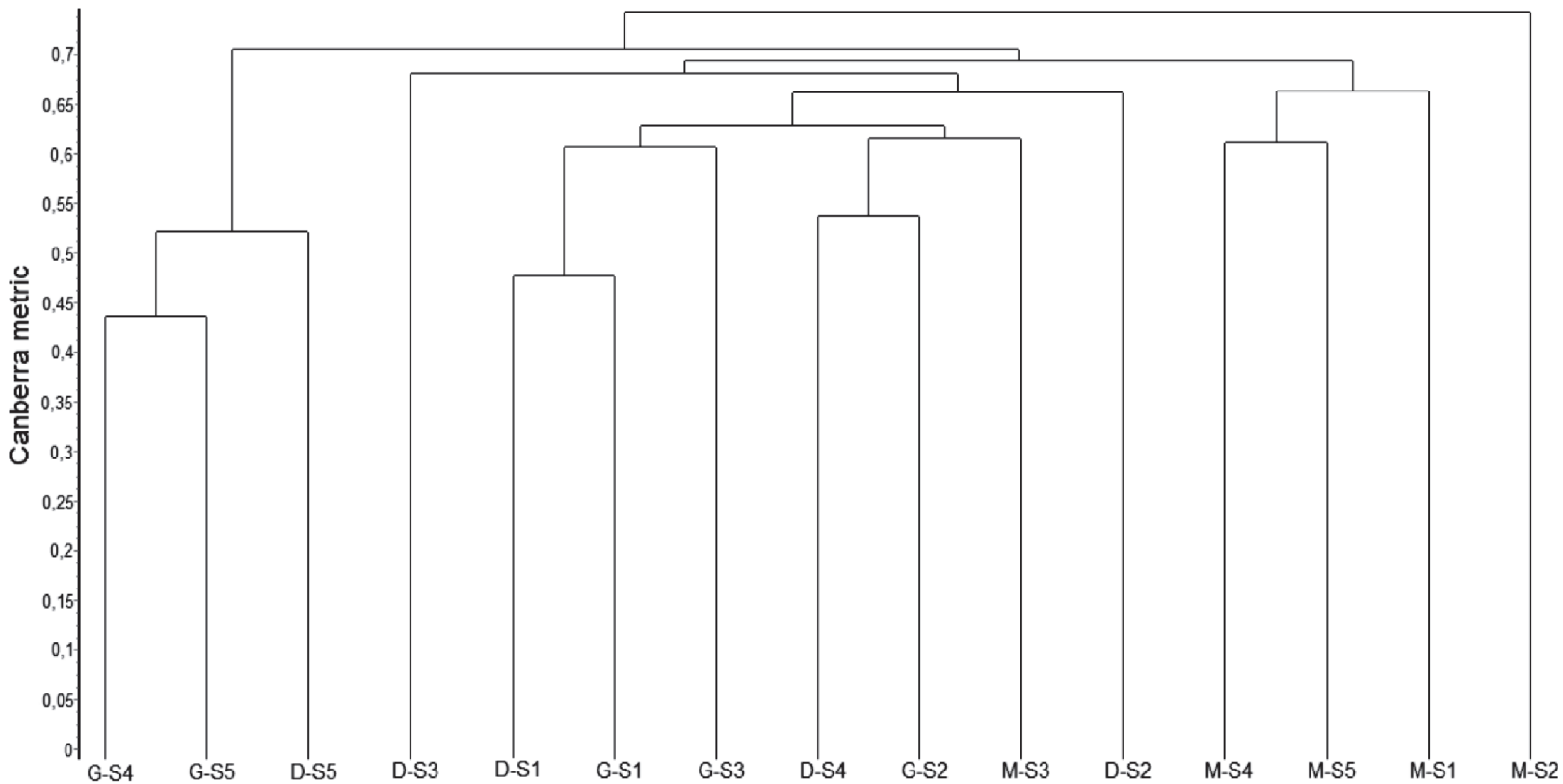

Figure 5 - Correspondence analysis (a) and dendrogram (b) of the 15 plots ( 3 merged) sampled in natural regeneration in Anchieta Island, Ubatuba, Brazil. Dendrogram was performed using canberra metric and average linkage method (UPGMA). See symbols and abreviations in figure 3.

Figura 5 - Análise de correspondência e dendrograma das 15 parcelas (3 agrupadas) amostradas na regeneração natural da Ilha Anchieta, Ubatuba, Brasil. O dendrograma foi obtido usando-se a distância de Canberra e o método de ligação por média de grupos (UPGMA). Vide símbolos e abreviações na figura 3.

Revista Árvore, Viçosa-MG, v.36, n.4, p.659-671, 2012 
accurately follow the pattern of spatial distribution of the three dominant vegetation types regarding their proximity of the remnant forests, which indicates that other factors are affecting natural regeneration. The first factor seems to be the fern effects on natural regeneration (SLOCUM et al., 2004). Clustering analysis showed most Miconia plots as a group apart of ferns (Figure 5b). Additionally, species richness and diversity were most frequently higher in the Miconia fields than in the fern thickets. Miconia fields showed larger number of herbs and shrubs (species and individuals), although herbs were mainly grasses and weeds (LORENZI, 2000).

Interestingly, Gleichenella and Dicranopteris fern thickets presented the tallest regenerating individuals. It seems to be a response of the seedling etiolation behavior imposed by physical barriers and low light availability in the fern thickets (RUSSEL et al., 1998; SLOCUM et al., 2004). Hypocotyl or epycotyl elongation increases seedling chances to emerging from litter or dense layer of fern fronds. However, it also increases risks of being fragile mainly by easy breaking and herbivory or fungal pathogens, which may result in increased mortality rates (GANADE; WESTOBY, 1999). A greater number of dead individuals were verified in the Gleichenella fern thickets. Also, possible allelopathic effects of Gleicheniaceae species cannot be ruled out (SOARES; VIEIRA, 2000). The results demonstrated a low capacity of natural regeneration in the fern thickets, confirming the already observed inhibitory effects of ferns on woody recruitment as well as the need of human intervention by restoration techniques to their forest recovery (COHEN et al., 1995; et al., 2007; SLOCUM et al., 2004).

According to Holl (1999) and Vieira and Scariot (2006), plant cover may increase seed germination and facilitate seedling development in abandoned pastures by enhancing shading and soil humidity. In degraded areas with sparse vegetation and large areas of poor and bare soil as in the Miconia fields, it is possible that seeds do not find these favorable conditions for germination and establishment. Indeed, preliminary results of the seed rain in the Island have showed no differences between Miconia fields and the understorey of remnant forest fragments (unpublished results), indicating the occurrence of barriers to germination and establishment. Furthermore, the poor seedling establishment in the Miconia fields may be a result of the downhill-rolling of seeds by gravity or flood waters (Pompéia et al., 1989) since differently to the fern thickets, in areas dominated by this species, the ground cover is very reduced. Sloping and bare lands such as the Miconia fields usually exhibit poorer, highly erodible, and more leached soils that may also hinder the seedling growth. The high values of plant density, species richness, and species diversity found in Praia do Engenho (MS2), the only Miconia plot randomly placed at the bottom of the hill where slope angles are lower may confirm the considerations above. Moreover, MS3 plot, which has the steepest slope (mean of $33^{\circ}$ ), were grouped apart from other Miconia fields and included in the major fern thicket cluster. A gradient of forest succession according to the slope was found by Chada et al. (2004), who also recorded greater regenerating density and species richness in the flattest or less sloping areas. Besides the lower susceptibility of leaching, plain areas may contain seed and organic material deposits that facilitate natural regeneration by improving edaphic conditions and providing plant propagules.

In spite of the favorable conditions for natural regeneration in MS2, tree species richness and density was low and similar to the other Miconia fields. Also, there was a great number of grasses, forage herbs and weeds in this plot (data not shown). It seems that there have been other barriers to the tree establishment in the site. Competition with grasses (HOLL et al., 2000) and the compaction of soil originated by the local construction of a road when the prison was active may be the ones.

Plots DS1, GS1 and GS3 were grouped together (Figure 5b) and presented higher values of tree density and richness than other fern thickets reaching similar values to the Miconia fields (Figures $3 c$ and $3 d$ ). Site 1 was the only site where there were no civil constructions in the prison period. Additionally, GS3 plot was delimited in the upper area of site 3, where there were no buildings, houses or structures either (V. BUCHIANERI, personal communication).

It is likely that land use type have differently affected the soil conditions of the fields (MBAGWU; AUERSWALD, 1999; YAO et al., 2000), resulting in the distinct regeneration responses observed above. Compaction of soil may have negatively influenced MS2 regeneration, while in the plots DS1, GS1, and

Revista Árvore, Viçosa-MG, v.36, n.4, p.659-671, 2012

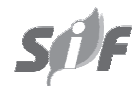


GS3, the farming effects themselves may have been less harmful. Although all sites have been intensively used, crops and constructions varied among sites. Thus, the differences found in composition and abundance of species among the study sites indicate that the type of land use may play an important role on natural regeneration in the fields.

Other factor that may negatively affect natural regeneration in the abandoned old fields, and also in the remnant forest fragments, is the presence of alien herbivores and nest predators, some of them overabundants in the island (BOVENDORP; GALETTI, 2007). According to Bovendorp and Galetti (2007) and Fadini (2005), the introduction of exotic species in the island may have contributed to the reduction of dispersal of tree seed dispersal due to population decline and/or extinction of disperser birds and the increase of tree seed and seedling predation by herbivores.

Although driven by different forces and the relatively richest composition and most complex structure of total regeneration in the Miconia fields, we considered that, in general, the capacity of tree regeneration in the three vegetation types were low (CHADA et al., 2004; KENNARD et al., 2002; RAYOL et al., 2006). Tree density values were in the range of those found in reforested areas: means of 0.3-0.6 individuals $\mathrm{m}^{-2}$ in Souza (2000) and 1.7 individuals $\mathrm{m}^{-2}$ in Siqueira (2002), but they were low even when compared to the most severely disturbed areas evaluated by Kennard et al. (2002) and very low compared to well conserved tropical forests (SIQUEIRA, 2002; SOUZA, 2000). Besides, tree richness in the natural regeneration of the three vegetation types was much lower than reforested areas (SIQUEIRA, 2002; SOUZA, 2000), with no record of late successional species (data not shown). Tree richness was only comparable with the seed bank richness of pastures abandoned 30-35 years ago at the Reserva Biológica de Poço das Antas, RJ, which have not showed any signs of forest recovery up to now (MORAES, 2005). Comparisons above indicated that the abandoned old fields have a pattern of seedling recruitment and establishment different from forested systems. Hence, we consider that the abandoned old fields are stagnated regarding to their return to forest conditions due to their intensive use lands and recommend some actions to accelerate the forest recovery.

Assisted natural regeneration is the simplest and the lowest-cost method to reforest degraded lands (SHONO et al., 2007). In areas with limited natural

Revista Árvore, Viçosa-MG, v.36, n.4, p.659-671, 2012 regeneration such as Miconia fields and fern thickets of AISP, human intervention is required to initiate recovery by removing or reducing barriers to natural forest regeneration. Some studies have showed that clearing of fern thickets results in rapid recruitment and growth of woody species (COHEN et al., 1995; SLOCUM, et al. 2004). Thus, we suggest, as a first restoration action for the fields, the fern removal in the fern thickets. Additionally, we recommend planting ground covers to improve physical and chemical soil conditions as well as to facilitate fixation of seeds and local germination and establishment. Likewise, recovery of ground cover in the Miconia fields is critical for the soil protection and the induction of local regenerating plant propagules (RODRIGUES; GANDOLFI, 2000). Moreover, monitoring the regenerating individuals after these restoration actions is necessary to evaluate if tree recruitment and establishment were restored. Aiming to promote and accelerate forest recovery, we also recommend the enrichment planting with tree species in the fields. The devastation and impoverishment of forests of the island (GUILLAUMON et al., 1989) as well as the absence of late successional species in the natural regeneration of the three vegetation types support this need (data not shown).

\section{CONCLUSIONS}

Results of natural regeneration in the abandoned fields of Anchieta Island demonstrated that the forest recovery after severe human disturbances is not direct, predictable or even achievable on its own. There was an intensive and prolonged land use associated with the continued effects of the introduction of animal exotic species in the island that severely affected the process of natural regeneration. A complex association of biotic and abiotic factors may explain the variation in composition and abundance of species in the study plots. The most important were competition with ferns, land use type, and slope. However, we recommend further studies in order to evaluate and to distinguish the effects of each ecological factor independently. Also, the lack of a natural forest recovery up to now, even with the proximity of remnant forests and the end of agricultural and livestock activities 30 years ago, indicated the need of a strong human intervention through restoration techniques 
in order to promote and to accelerate the reestablishment of a functional forest community in the abandoned old fields.

\section{ACKNOWLEDGMENTS}

We thank L.B. Aranha for helping us with maps and slope estimates and P.H.S. Brancalion and two anonymous referees for critical comments on the manuscript. Special thanks to V. Buchianeri and all the employees of Anchieta Island State Park (AISP). This work was supported by AISP, Fundação para a Conservação e a Produção Florestal do Estado de São Paulo. M.S. and L.G.V. were supported by São Paulo Research Foundation (FAPESP). A.D.C. and A.L.L were supported by The National Council for Scientific and Technological Development (CNPq).

\section{REFERENCES}

BOVENDORP, R. S.; GALETTI, M. Density and population size of mammals introduced on a land-bridge island in southeastern Brazil. Biological Invasions, v.9, n.3, p.353-357, 2007.

CHADA, S. S.; CAMPELLO, E. F. C.; FARIA, S. M. Sucessão vegetal em uma encosta reflorestada com leguminosas arbóreas em Angra dos Reis, RJ. Revista Árvore, v.28, n.6, p.801-809, 2004.

COHEN, A. L.; SINGHAKUMARA, B. M. P.; ASHTON, P. M. S. Releasing rain forest succession: A case study in the Dicranopteris linearis Fernlands of Sri Lanka. Restoration Ecology, v.3, n.4, p.261-270, 1995.

DEAN, W. With broadax and firebrand: the destruction of the Brazilian Atlantic forest. Berkeley: University of California Press, 1995.

FADINI, R. F. Limitações bióticas afetando o recrutamento da palmeira Euterpe edulis em uma Ilha Continental da Mata Atlântica. 2005. 78f. Dissertação (Mestrado em Ciências Biológicas) - Universidade Estadual Paulista, Rio Claro, 2005.

GANADE, G.; WESTOBY, M. Seed mass and the evolution of early-seedling etiolation. The American Naturalist, v.154, p.469-480, 1999.
GUillaumon, J. R. et al. Plano de Manejo do Parque Estadual da Ilha Anchieta. IF-São Paulo: 1989. (Série Registros, 1)

HOLDRIDGE, L. R. Life zone ecology. San Jose: Tropical Scientific Center, 1967.

HOLL, K. D. Factors limiting tropical rain forest regeneration in abandoned pasture: seed rain, seed germination, microclimate, and soil. Biotropica, v.31, n.2, p.229-242, 1999.

HOLL, K. D. et al. Tropical Montane Forest Restoration in Costa Rica: overcoming barriers to dispersal and establishment. Restoration Ecology, v.8, n.4, p.339-349, 2000.

FUNDAÇÃOINSTITUTO BRASILEIRODE GEOGRAFIA E ESTATÍSTICA - IBGE. Manual técnico da vegetação brasileira - Rio de Janeiro: 1992. (Manuais Técnicos de Geociências, 1).

KENNARD, D. K. et al. Effects of disturbance intensity on regeneration mechanisms in a tropical dry forest. Forest Ecology and Management, v.162, n.1/2, p.197-208, 2002.

LANCE, G. N.; WILLIAMS, W. T. Computer programs for classification. In: ANCCAC CONFERENCE, 1966, Canberra. Proceedings... Canberra: 1966. 282p. (Paper 12/3)

LEGENDRE, L.; LEGENDRE, P. Numerical ecology. 2.ed. Amsterdam: Elsevier, 1998.

LEITÃO FILHO, H. F. Considerações sobre a florística de florestas tropicais e sub-tropicais do Brasil. Instituto de Pesquisas e Estudos Florestais, v.35, p.41-46, 1987.

LORENZI, H. Plantas daninhas do Brasil: terrestres, aquáticas, parasitas e tóxicas. 3.ed. Nova Odessa: Instituto Plantarum de Estudos da Flora, 2000

MAGURRAN, A. E. Ecological diversity and its measurement. Princeton: Princeton University, 1988.

MBAGWU, J. S. C.; AUERSWALD, K. Relationship of percolation stability of soil aggregates to land use, selected properties, structural indices and simulated rainfall erosion. Soil \& Tillage Research, v.50, n.3/4, p.197-206, 1999.

Revista Árvore, Viçosa-MG, v.36, n.4, p.659-671, 2012 
MCGILL, R.; TUKEY, J. W.; LARSEN, W. A. Variations of box plots. The American Statistician, v.32, n.1, p.12-16, 1978.

MORAES, L. F. D. Indicadores da restauração de áreas degradadas na Reserva Biológica de Poço das Antas, RJ. 2005. 111f. Tese (Doutorado em Ciências) Universidade Federal Rural do Rio de Janeiro, Seropédica, 2005.

MÜLLER, C. et al. Potencial fitotóxico de algumas espécies Gleicheniaceae sobre Allium cepa L. Revista Brasileira de Biociências, v.5, n.1, p.45-47, 2007.

MUÑIZ-CASTRO, M.; WILLIAMS-LINERA, G.; BENAYAS, J. M. Distance effect from cloud forest fragments on plant community structure in abandoned pastures in Veracruz, Mexico. Journal of Tropical Ecology, v.22, n.4, p.431-440, 2006.

PANIZZA, A. C. Imagens orbitais, cartas e coremas: uma proposta metodológica para o estudo da organização e dinâmina espacial, aplicação ao Município de Ubatuba, Litoral Norte do Estado de São Paulo, Brasil. 2004. 302f. Tese (Doutorado em Geografia) - Universidade de São Paulo, São Paulo, 2004.

POMPÉIA, S. L. et al. A semeadura aérea na Serra do Mar em Cubatão. Ambiente, v.3, n.1, p.13-19, 1989.

RAYOL, B. P.; SILVA, M. F. F.; ALVINO, F. O. Dinâmica da regeneração natural de florestas secundárias no município de Capitão Poço, Pará, Brasil. Amazônia, v.3, n.1, p.93-110, 2006.

REIS-DUARTE, R. M. Estrutura da Floresta de Restinga do Parque Estadual Ilha Anchieta (SP): bases para promover o enriquecimento com espécies arbóreas nativas em solos alterados. 2004. 230 f. Tese (Doutorado em Ciências Biológicas) Universidade Estadual Paulista, Rio Claro, 2004.

RODRIGUES, R. R.; GANDOLFI, S. Conceitos, tendências e ações para recuperação de florestas ciliares. In: RODRIGUES, L. M.; LEITÃO-FILHO, H. F., eds. Matas ciliares: conservação e recuperação. São Paulo: EDUSP/FAPESP, 2000. p.235-248.
RUSSEL, A. E.; RAICH, J. W.; VITOUSEK, P. M. The ecology of the climbing fern Dicranopteris linearis on windward Mauna Loa, Hawaii. Journal of Ecology, v.86, n.5, p.765-779, 1998.

SETZER, J. Atlas climático e ecológico do Estado de São Paulo. São Paulo: Comissão Interestadual da Bacia do Paraná Uruguai/Centrais Elétricas de São Paulo, 1966.

SIQUEIRA, L. P. Monitoramento de áreas restauradas no interior do Estado de São Paulo, Brasil. 2002. 116f. Dissertação (Mestrado em Recursos Florestais) - Escola Superior de Agricultura Luiz de Queiroz, Universidade de São Paulo, Piracicaba, 2002.

\section{SHEPHERD, G. J. FITOPAC 2.1 Versão}

Preliminar. Campinas: Departamento de Biologia Vegetal, Universidade Estadual de Campinas, 2009.

SHONO, K.; CADAWENG, E. A.; DURST, P. B. Application of assisted natural regeneration to restore degraded Tropical Forestlands. Restoration Ecology, v. 15, n.4, p.620-626, 2007.

SLOCUM, M. G. et al. Natural regeneration of subtropical montane forest after clearing fern thickets in the Dominican Republic. Journal of Tropical Ecology, v.20, n.4, p.483-486, 2004.

SECRETARIA DO MEIO AMBIENTE - SMA. Fauna ameaçada no Estado de São Paulo. SMA do Estado de São Paulo (SMA/ CED). São Paulo: 1998. (Série PROBIO/SP)

SOARES, G. L. G.; VIEIRA, T. R. Inibição da germinação e do crescimento radicular de alface (cv."grand rapids") por extratos aquosos de cinco espécies de Gleicheniaceae. Floresta e Ambiente, v.7, n.1, p.180-197, 2000.

SOKAL, R. R.; ROHLF, F. J. Biometry (The principles and practice of statistics in biological research). New York: Freeman, 1995.

SOUZA, F. M. Estrutura e dinâmica do estrato arbóreo e da regeneração natural em áreas restauradas. 2000. 69f. Dissertação (Mestrado em Ciências) - Escola Superior de Agricultura Luiz de Queiroz, Universidade de São Paulo, Piracicaba, 2000. 
TABANEZ, A. J.; VIANA, V. M.; DIAS, A. S. Conseqüências da fragmentação e do efeito de borda sobre a estrutura, diversidade e sustentabilidade de um fragmento de floresta de planalto de Piracicaba, SP. Revista Brasileira de Biologia, v.57, n.1, p.47-60, 1997.

TABARELLI, M.; MANTOVANI, W. A riqueza das espécies arbóreas na floresta atlântica de encosta no estado de São Paulo (Brasil).

Revista Brasileira de Botânica, v.22, n.2, p.217-233, 1999.

TABARELLI, M. et al. Prospects for biodiversity conservation in the Atlantic Forest: Lessons from aging human-modified landscapes. Biological Conservation, v. 143, n.10, p.2328-2340, 2010
TORRES, R. B.; MARTINS, F. R.; KINOSHITA, L. $\mathrm{S}$. Climate, soil and tree flora relationships in forests in the state of São Paulo, Southestern Brazil. Revista Brasileira de Botânica, v.20, n.1, p.41-49, 1997.

UHL, C.; CLARK, H.; CLARK, K. Successional patterns associated with slash-and-burn agriculture in the upper Rio Negro Region of the Amazon Basin. Biotropica, v. 14, p.249-254, 1982.

VIEIRA, D. L. M.; SCARIOT, A. Principles of natural regeneration of tropical dry forests for restoration. Restoration Ecology, v.14, n.4, p.11-20, 2006.

YAO, H. et al. Microbial biomass and community structure in a sequence of soils with increasing fertility and changing land use. Microbial Ecology, v.40, n.3, p.223-237, 2000. 
